\title{
Proposal for Ichnotaxonomic Allocation of Therapsid Footprints from the Botucatu Formation (Brazil)
}

\author{
Simone D'Orazi Porchetti, Reinaldo J. Bertini \& Max C. Langer
}

To cite this article: Simone D'Orazi Porchetti, Reinaldo J. Bertini \& Max C. Langer (2018) Proposal for Ichnotaxonomic Allocation of Therapsid Footprints from the Botucatu Formation (Brazil), Ichnos, 25:2-3, 192-207, DOI: 10.1080/10420940.2017.1308929

To link to this article: https://doi.org/10.1080/10420940.2017.1308929

曲 Published online: 19 Apr 2017.

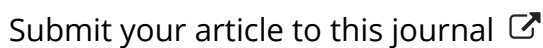

山ll Article views: 120

View Crossmark data $\sqsubset$

Citing articles: 2 View citing articles $\square$ 


\title{
Proposal for Ichnotaxonomic Allocation of Therapsid Footprints from the Botucatu Formation (Brazil)
}

\author{
Simone D'Orazi Porchetti ${ }^{\mathrm{a}}$, Reinaldo J. Bertini ${ }^{\mathrm{b}}$, and Max C. Langer (D) ${ }^{\mathrm{a}}$

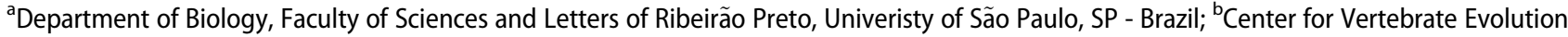 \\ and Paleobiology, Department of Applied Geology, Institute of Geosciences and Exact Sciences, São Paulo State University (UNESP) - Campus \\ Rio Claro, SP - Brazil
}

\begin{abstract}
A new ichnospecies, Brasilichnium anaiti, is erected on material from the Botucatu Formation of Brazil. The general morphology supports ichnotaxonomic similarity between the new ichnotaxon and Brasilichnium elusivum Leonardi, 1981, even if a separation at the ichnospecies level is evident, based on differences in shape and arrangement of pes digit marks along with a clear dimensional gap between both ichnotaxa. Similar forms from the Lower Jurassic of the United States are known and should be included under this new ichnotaxonomic label, based on shared morphological features. B. anaiti is constantly associated with B. elusivum in dune foresets of hyperarid paleoenvironments, to which these forms are restricted. This makes $B$. anaiti a further element of the Brasilichnium ichnocoenosis in the larger framework of the Chelichnus ichnofacies. Reevaluation of possible trackmakers highlights the difficulties of unequivocal referring this ichnotaxon to a specific producer, but restrains potential trackmakers to early mammaliamorph therapsids.
\end{abstract}

\section{KEYWORDS}

Botucatu Formation;

Brasilichnium anaiti; Brazil;

Mammaliamorph therapsids;

Paleoerg

\section{Introduction}

With extensive work of collection and description of vertebrate footprints, Leonardi (1977a, 1977b, 1980, 1981, 1989, 1994) and coworkers (Leonardi and Godoy, 1980; Leonardi and Sarjeant, 1986; Leonardi and Oliveira, 1990; Leonardi and Carvalho, 1999; Leonardi et al., 2007) have greatly improved our knowledge of the Brazilian Mesozoic ichnological record. Brasilichnium elusivum (Leonardi, 1981) is probably the most renowned ichnotaxon erected on Brazilian material, a name successively adopted to identify ichnites from the Early Jurassic of North America (see Lockley, 2011). Nonetheless, quadrupedal morphotypes other than B. elusivum were described from the Botucatu Formation (Leonardi, 1977a; Leonardi, 1980; Leonardi and Godoy, 1980), although never allocated ichnotaxonomically. These footprints, which have been referred to as "theromorphoid" (possible Tritylodontoidea tracks, see Leonardi and Sarjeant, 1986), are well represented in fossil collections and remarkable specimens are stored at the Paleontology and Stratigraphy Museum, UNESP Campus Rio Claro (São Paulo, Brazil). In this work we examine and describe this material, and propose a new name to identify a specific morphotype. Possible trackmakers are also investigated.

\section{Geological setting}

The Botucatu Formation represents a huge accumulation of eolian sandstones, deposited inside a large intracratonic basin (Paraná Basin). In São Paulo State (southeastern Brazil), the Botucatu Formation rests unconformably over the Piramboia Formation, and it is covered by the basaltic lava extrusions of the Serra Geral Formation (Assine et al., 2004). The extension of the Botucatu paleodesert makes it one of the largest in Earth history with an estimated extension of 1.3 millions squared kilometers (Almeida, 1954). It extends over most of the southern portion of Brazil (Goiás, Mato Grosso, Mato Grosso do Sul, São Paulo, Paraná, Santa Catarina, Rio Grande do Sul states) and Botucatu lateral equivalents crop out in Uruguay (Tacuarembó Formation partim Perea et al., 2009), Paraguay (Misiones Formation, Leonardi, 1992), and Argentina (Sanford and Lange, 1960; Salamuni and Bigarella, 1967) (Fig. 1). The Twyfelfontein Formation (Namibia) is considered the African portion of the Botucatu paleodesert (Stollhofen, 1999), and the recent finding of possible Brasilichnium footprints in this unit strengthened that correlation (D’Orazi Porchetti and Wagensommer, 2015). 


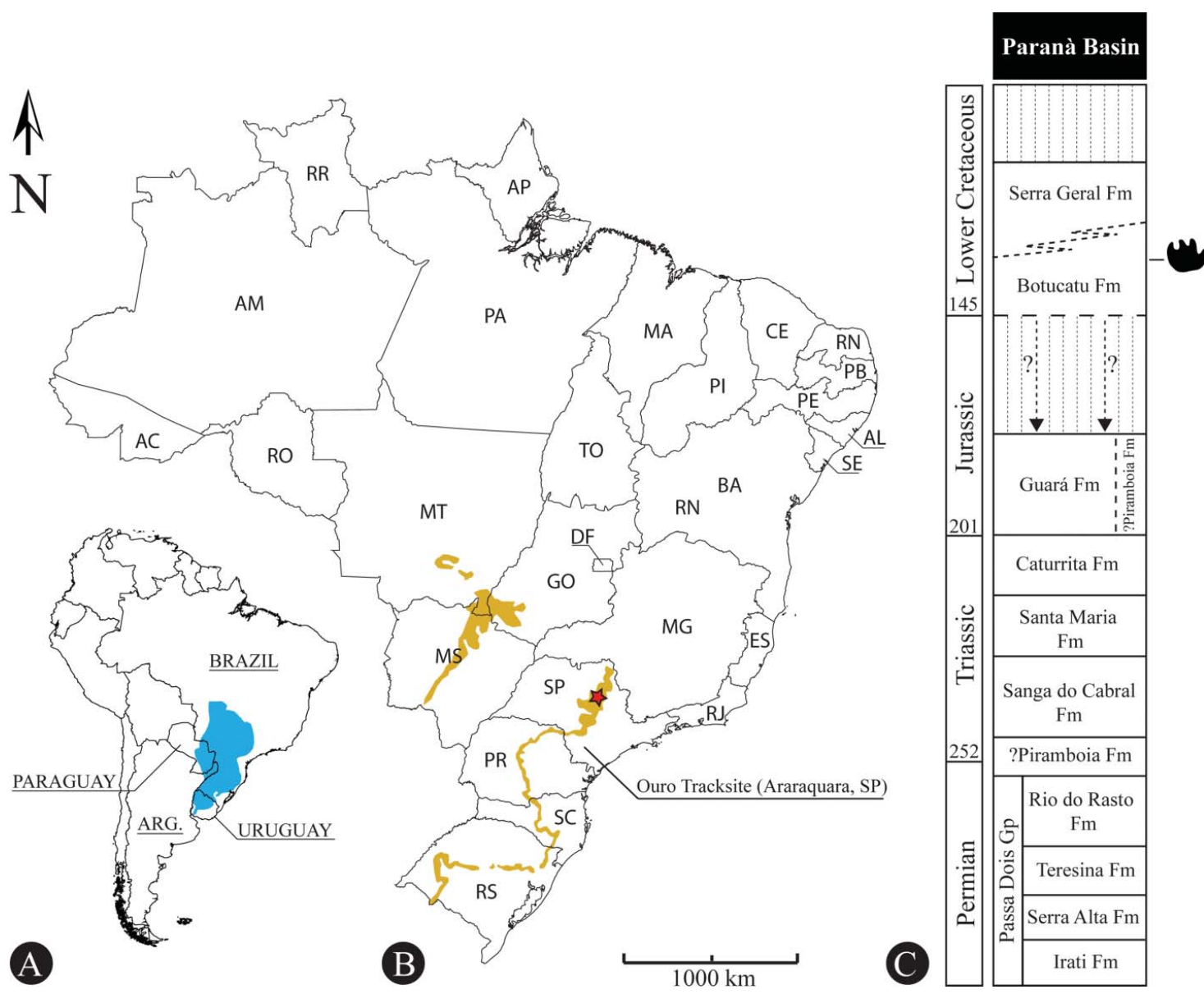

Figure 1. A. The Paraná Basin (in blue) extends over Brazil, Paraguay, Uruguay, and Argentina. B. Geographic location of Corpedras quarry (red star), and distribution of the Botucatu Formation outcrops (ochre) on the Brazilian territory. C. Simplified stratigraphy of the Paraná Basin. The age of the Piramboia Formation is controversial (Soares, 1975; Scherer, 2000; Soares et al., 2008). For this reason, it is presented twice, with question marks. Base maps in A) and B) from Creative Commons.

The age of the Botucatu sandstones has been extensively discussed in recent decades, with dating that spans from the Late Triassic (Almeida, 1954) to the Early Cretaceous (Scherer, 2000, 2002). This uncertainty is due to the lack of unequivocal direct rock dating and to the absence of index fossils. The exclusive, albeit abundant, fossil record of the Botucatu Formation consists of tetrapod traces fossil and, to a lesser extent, invertebrate trace fossil. Based on comparisons with similar ichnofaunas, an age not younger than the Middle Jurassic was proposed (Leonardi and Oliveira, 1990; Bonaparte, 1996) for this lithostratigraphic unit. Other lines of evidence, unrelated to fossils, pushed the presumed age of the Botucatu Formation to the Early Cretaceous (Scherer, 2000, 2002; Tamrat and Ernesto, 2006). This is the age for the Serra Geral Formation, as calculated from isotopic analyses $\left({ }^{40} \mathrm{Ar} /{ }^{39} \mathrm{Ar}\right.$; Renne et al., 1992; Turner et al., 1994). An age between 134.5 \pm 2.1 and $119.3 \pm 0.95 \mathrm{Ma}$, has recently been proposed by Brückmann et al. (2014) after analysis on U-PB (SHRIMP) data from magmatic zircon crystals.
Presence of sand dunes inside the Serra Geral Formation proves that the desert was active at the time of the basalt floods, and therefore, its age could not be much older than the basaltic effusion itself (Scherer, 2000, 2002).

\section{Institutional abbreviations}

CU-MWC: University of Colorado and Museum of Western Colorado joint collection; CU: University of Colorado; MPA: "Material Paleontológico de Araraquara"; URC (R/M): Museu de Paleontologia e Estratigrafia "Prof. Dr. Paulo Milton Barbosa Landim", Instituto de Geociências e Ciências Exatas (IGCE), Universidade Estadual Paulista Júlio de Mesquita Filho (UNESP), Rio Claro Campus.

\section{Materials and methods}

The material studied here is stored at the Museu de Paleontologia e Estratigrafia "Prof. Dr. Paulo Milton 
Barbosa Landim", UNESP Campus in Rio Claro City. Hereafter we will refer to it as the "Rio Claro Collection" for brevity. The slabs preserved at the Rio Claro Collection were collected over 13 years (1987-2000) at the São Bento (also known in literature as Corpedras) sandstone quarry in Araraquara Municipality, São Paulo State. Mining activity exploited what possibly were the seasonal or annual boundaries between sets of smaller strata, and many specimens are by-product of such activity. Since 2003 the São Bento Quarry was no longer prospected. Slabs were extracted from sets of cross-strata inclined on average to 26 degrees (Leonardi, 1980). Tracks are impressed either on centimetric (up to $15 \mathrm{~cm}$ ) packs of grainflow sandstone or on thinner, highly laminated blocks, generated by superimposition of wind ripple strata. Most of the sample probably comes from the basal portion of the slip face of the dune, which is usually not eroded by deflation or superimposition of overcoming dunes, and where the sand avalanches are prominently depositional. The presence of climbing wind ripples is congruent with this interpretation, as the toe of the leeward face is the place where inversion of annual dominant winds and/or deflected air fluxes usually gives place to this type of deposition (Pye and Tsoar, 2009; Bristow and Mountney, 2013).

Eight sandstone slabs yielded "theromorphoid" tracks, mostly organized in short trackways. A total of 41 pes traces, associated to 19 manus traces, have been analyzed first-hand and are described here for the first time. The material is identified by the following collection numbers URCR.70, URCR.110, URCR.111, URCR.112, URCR.115, URCR.138, URCR.142, URCM.41, but these refer only to the footprint-bearing slab. As one slab (URCM.41) yields more than one trackway and different morphotypes, we added here specific letters to identify the sequence of tracks under analysis, in accordance to the illustrations and graphics provided in this work. Tracks are preserved both as concave epirelief and convex hyporelief. All footprints have been photographed, reproduced on transparent films, and 3D virtual models of selected specimens have been performed with a close-range photogrammetric approach (see Falkingham, 2012 for details). For our purposes, we measured the footprint length at the intersection with the plane of the undisturbed slab surface, also defined as the "zone of negative vertical displacement" (Falkingham, 2016), with the exclusion of the expulsion rims. The ichnological terminology we use here follows Leonardi (1987) and Thulborn (1990). In this article, we adopted a new labelling for the Botucatu Formation slabs, which is specific for the Rio Claro Collection. The new acronyms, URCR and URCM, are adopted here instead of the original one (ARSB) introduced by Giuseppe Leonardi. Correspondence between old and new labelling for the examined material is as follows, ARSB. 200 = URCR.70; ARSB.262 = URCR.110; ARSB.257 = URCR.11; ARSB.256 = URCR.112; ARSB.285 = URCR.115; ARSB.258 = URCR.138; ARSB. $288=$ URCR.142; ARSB.244 = URCM.41.

\section{Systematic ichnology}

\section{Ichnogenus Brasilichnium (Leonardi, 1981)}

Emended diagnosis: Quadrupedal trackways, with neat heteropody. Tetradactyl manus print, digitigrade, usually three- to two-digit marks are preserved, isolated from each other. Tetradactyl pes prints, with average length/ width ratio around 0.7. Pes digit marks are short, and usually separated from the metapodial marks; drop-like, proximally rounded, and distally pointed, to elliptical pes digit marks. Pes digit marks II and III the largest, digit III dominant in terms of length. Digit mark IV usually stout, distally blunt. Manus and pes digit marks formed by single pad. Palm print rounded, wider than long, anteriorly and posteriorly convex. No tail mark.

Type ichnospecies Brasilichnium elusivum (Leonardi, 1981)

Brasilichnium anaiti isp. nov.

Figs. 2 and 3

Etymology: Anaití means large in the native Brazilian Tupí-Guaraní language. This name refers to the larger size of this form compared to Brasilichnium elusivum.

Holotype: URCR.70, a sequence of 11 pes and 12 manus prints. Footprints preserved as concave epirelief.

Paratype series: URCR.110: the slab is broken in 9 pieces, and now recomposed inside a wooden box; six footprints are preserved as concave epirelief, the first is incomplete proximally; three hand prints are associated to pes traces 1,3 , and 5 .

URCR.111: Slab with a sequence of four footprints; two partial handprints are associated to pes traces 1 and 3 ; the first pes trace is only partially preserved, and the pertaining expulsion rim is preserved on URCR.110. This trackway is actually the prosecution of that on URCR.110, as the two slabs were originally a single, larger one (URCR.110 + URCM.111 have in total 10 footprints and 5 handprints). Tracks preserved as concave epirelief.

URCR.112: Three pes prints in sequence, associated to three very shallow hand prints; the manus print associated to footstep number 2 shows two small round marks at the tip of a shallow depression. Tracks preserved as concave epirelief.

URCR.115: Four footmarks and one handprint, in a single trackway. Tracks preserved as convex hyporelief. 

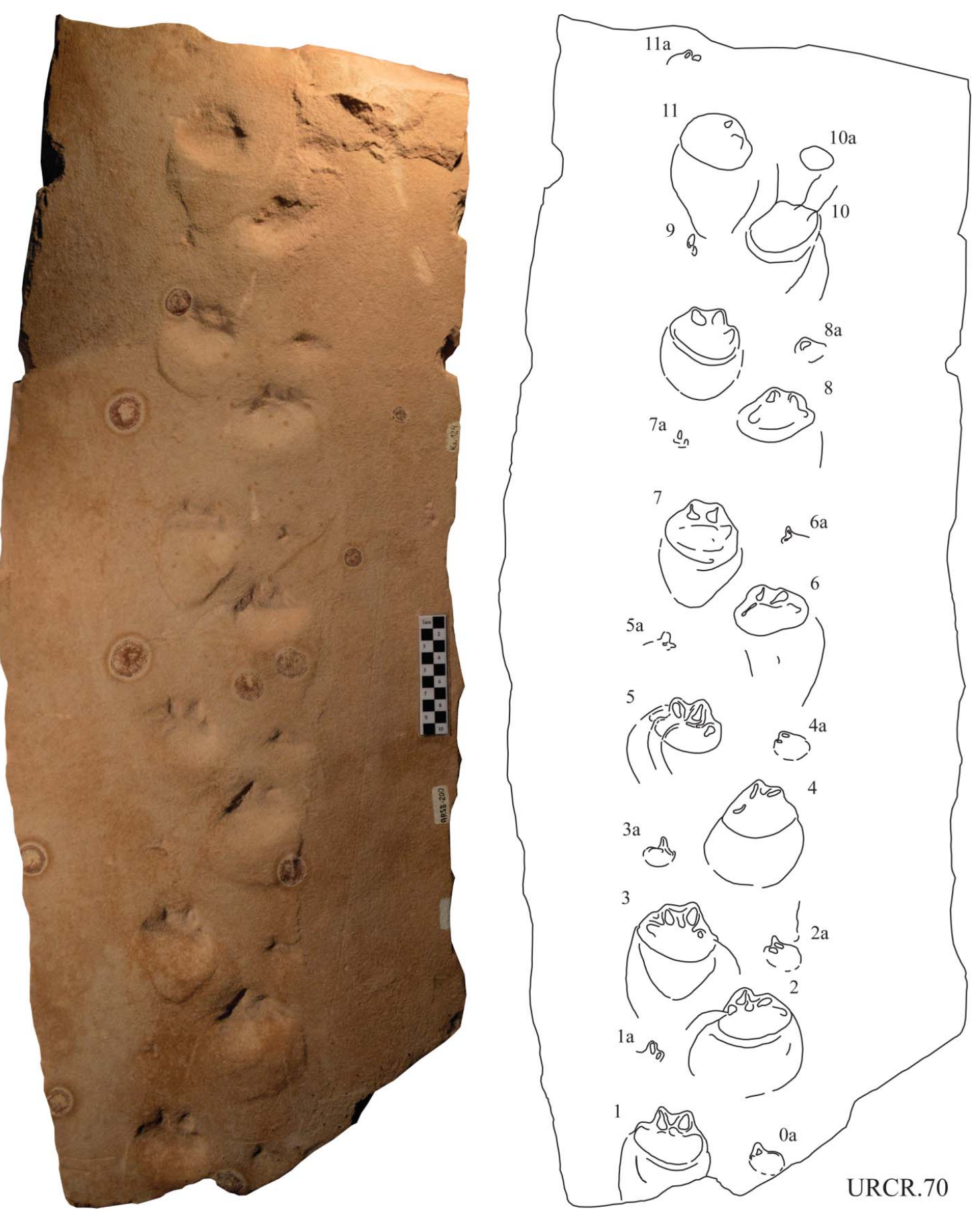

Figure 2. Holotype slab URCR.70 (left), and relative drawing (right). Footprints are numbered in sequence, from the bottom to the top of the figure. Handprints are marked with the same number of the associated footprints followed by the letter $a$ (i.e., URCR.70-1a).

URCM.41: Large slab with at least five large footprints, organized in a trackway (trackway A); no hand prints pertaining to this trackway are visible (other trackway and isolated footprints are present on this slab but pertains to Brasilichnium elusivum).

\section{Referred material:}

1980 “pistas Teromorfóides," fig. 2A-2B, p. 3085, Leonardi and Godoy.
1980 “pistas teromorfóides,” figs. 5A-D, p. 3088, Leonardi and Godoy.

1986 "A theromorphoid trackway from the pavements of São Carlos," fig. 7, p. 80, Leonardi and Sarjeant.

1990 "Theromorphoid footprints from Botucatu Formation," plate XI A-E, p. 224. Leonardi and Oliveira. 

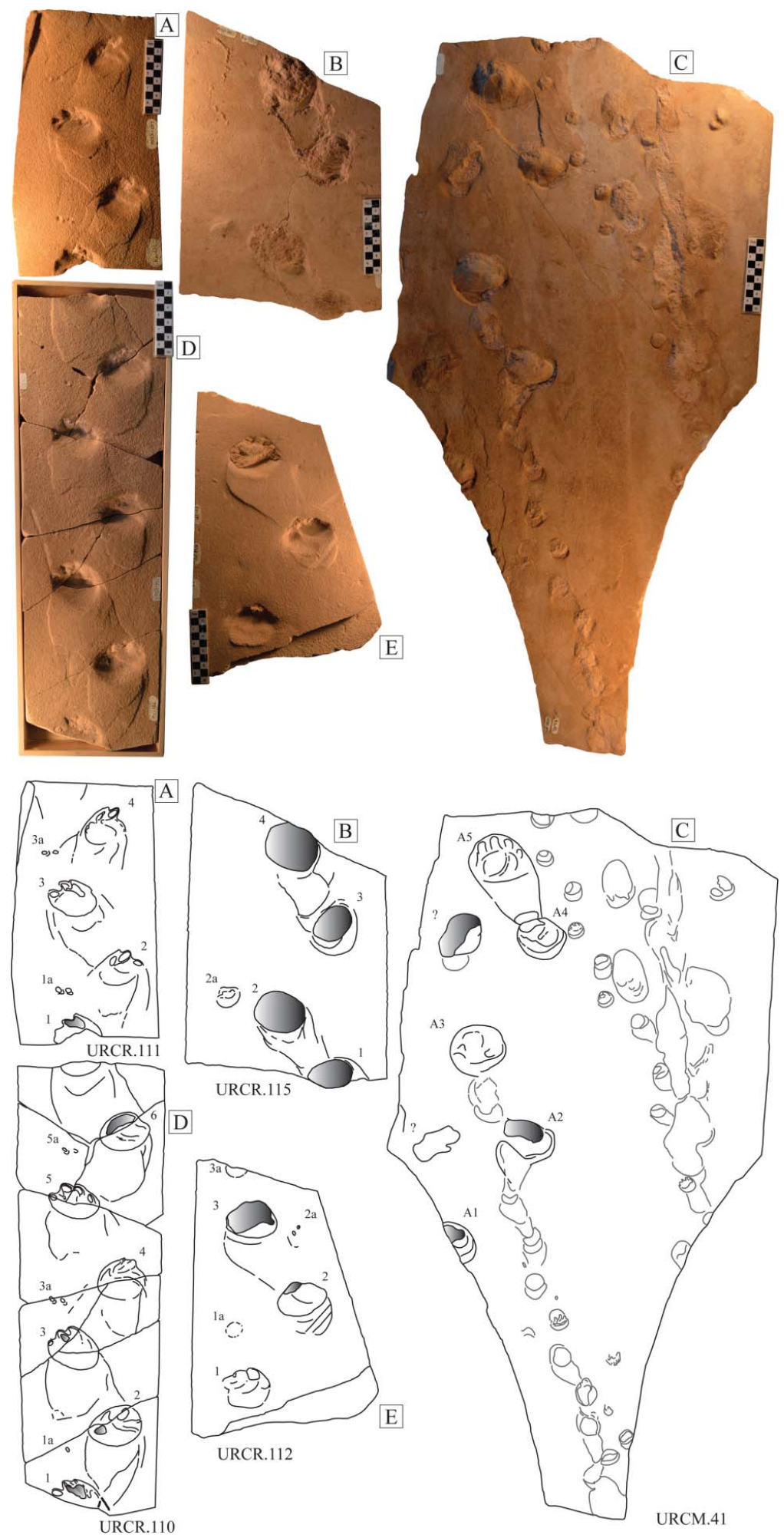

Figure 3. Paratype series with slabs A. URCR.111, B. URCR.115, C. URCM.41, D. URCR.110, and E. URCR.112. On URCM.41 B. anaiti is in black, whereas $B$. elusivum trackways are represented in grey. Halftones cover eroded portions of the footprints. Scale bar $10 \mathrm{~cm}$.

1999 "Pegadas teromorfóides atribuídas à ?Tritylodontoidea," fig. 2A-C, p. 44, Leonardi and Carvalho.

2007 "Theromorphoid footprint attributed to relative bigger mammals," fig. 3A-C, p. 384, Leonardi, Carvalho, and Fernandes.
Repository: Museu de Paleontologia e Estratigrafia Prof. Dr. Paulo Milton Barbosa Landim, Instituto de Geociências e Ciências Exatas (IGCE), Universidade Estadual Paulista Júlio de Mesquita Filho (UNESP), Rio Claro Campus, São Paulo State (Brazil). 


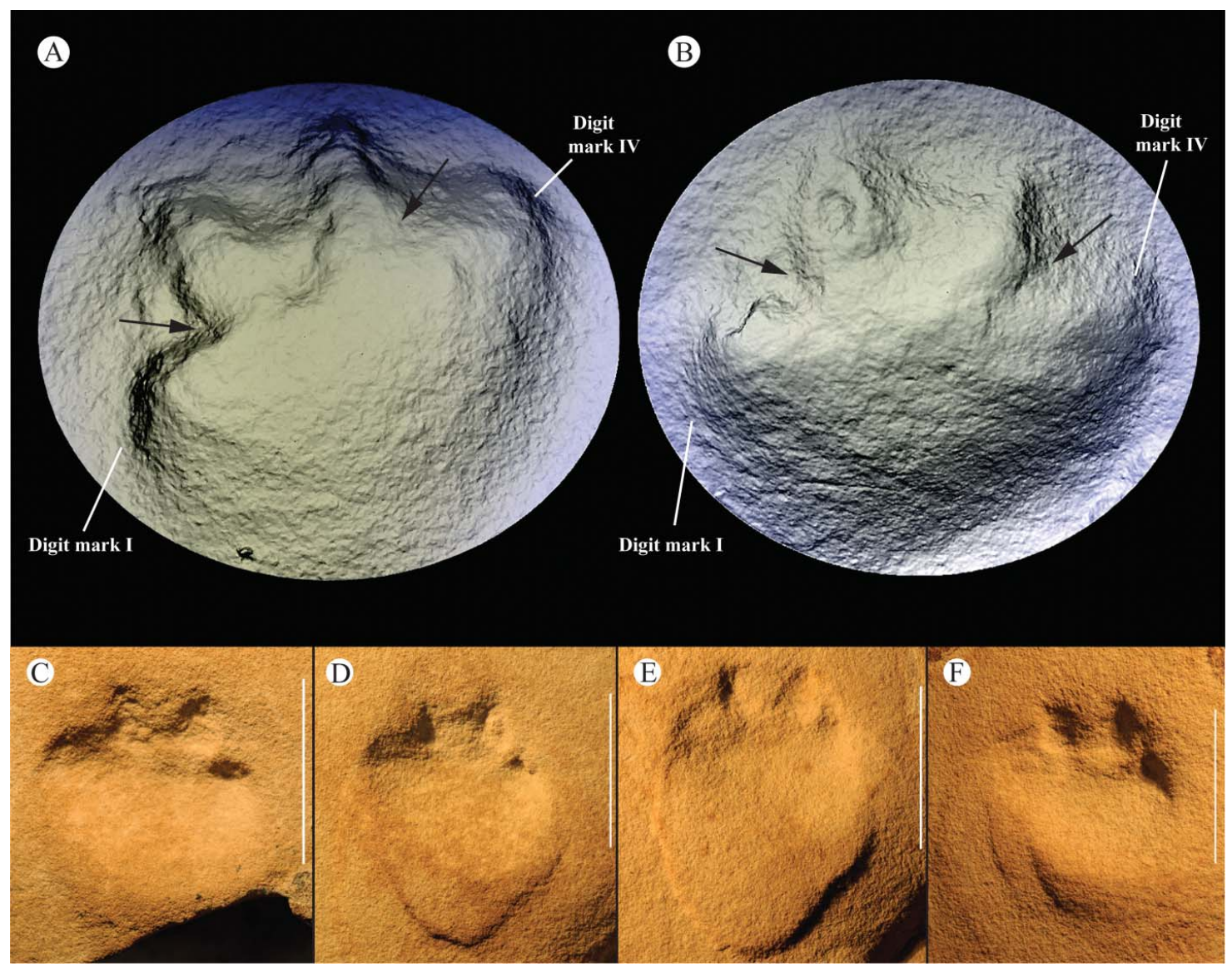

Figure 4. Three-dimensional model of A. URCR.70-1 and B. URCR.70-2, obtained from modelling clay cast of the original footprints. Black arrows to show the stenosis at the base of the central digits, effect of the digital arcade in trackmaker's acropodium. Close-up views of C. URCR.70-1, D. URCR.70-3, E. URCR.70-5, and F. URCR.70-7. Trackway midline to the right of each footprint. Scale bar $5 \mathrm{~cm}$.

Type Locality and Horizons: Corpedras sandstone quarry, Araraquara Municipality, São Paulo State, Brazil. Botucatu Formation.

Distribution: ?Middle Jurassic-Early Cretaceous of Brazil.
Ichnospecific diagnosis: Quadrupedal trackway, with neat heteropody, pes print larger than manus print; tetradactyl, paraxonic-to-slightly ectaxonic pes print; foot digit marks are short, usually separated from metapodials by a stenosis or groove (especially

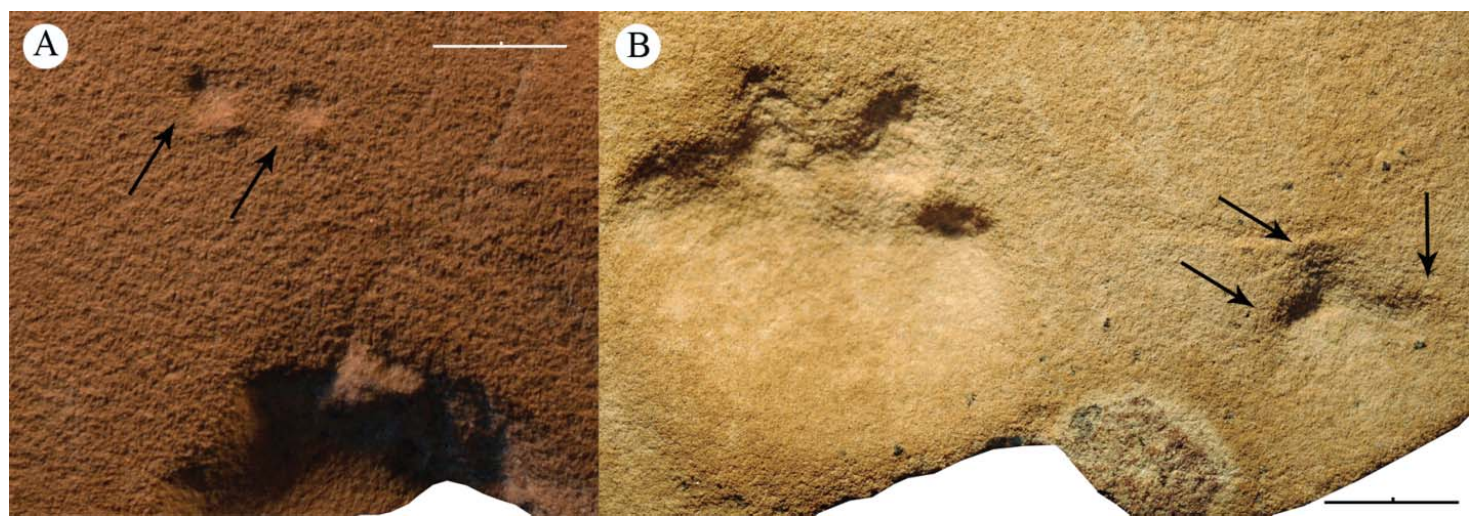

Figure 5. Detail of manus prints. A. URCR.110-1a. B. URCR.70-0a. Black arrows show single digit marks. Only two digit marks are preserved in A), possibly corresponding to the lateral ones of B), where three digit marks are visible. Difference in colour tones between A) and B) is partly due to different light conditions during photo shooting. Scale bar $2 \mathrm{~cm}$. 
Table 1. From left to right, $\left(\right.$ Rep. $\left.\mathrm{N}^{\circ}\right)$ : repository numbers. $\left(\mathrm{N}^{\circ}\right.$ of pes traces): number of pes marks for each trackway. ( $\mathrm{N}^{\circ}$ of manus traces): number of manus traces in the trackway. (Trackway Length): length of the trackway $(\mathrm{mm})$. (Trackway Width): maximum external width of the trackway $(\mathrm{mm})$. Asterisk for the holotype (URCR.70).

\begin{tabular}{lcccc}
\hline Rep. No. & $\begin{array}{c}\text { No. of Pes } \\
\text { Traces }\end{array}$ & $\begin{array}{c}\text { No. of Manus } \\
\text { Traces }\end{array}$ & $\begin{array}{c}\text { Trackway } \\
\text { Length }\end{array}$ & $\begin{array}{c}\text { Trackway } \\
\text { Width }\end{array}$ \\
\hline URCM.41 & 5 & $\mathrm{n} / \mathrm{a}$ & 58 & 15 \\
URCR.70* & 11 & 12 & 96 & 15 \\
URCR.110 & 7 & 2 & 59 & 12.5 \\
URCR.111 & 4 & 2 & 45 & 13 \\
URCR.112 & 3 & 2 & 29 & 15 \\
URCR.115 & 4 & 1 & 36 & 17 \\
URCR.138 & 2 & n/a & n/a & n/a \\
URCR.142 & 5 & n/a & n/a & n/a \\
\hline
\end{tabular}

on the centrals two digits), giving the footmark a paw-like appearance. First and fourth pes digit marks distally blunt, whereas the second and third appear distally sharp. Digit marks I-III are more deeply impressed compared to the lateral one, with the deepest area corresponding to the metatarsal-phalangeal joints. Pes print wider than long, with an average FL/ FW ratio of 0.72 . Manus print with at least three digit marks, always preceding the footmarks. No tail marks have been observed. Typically found on the foreset of sand dunes in hyperarid environments, usually in association with Brasilichnium elusivum.

The new ichnospecies differs from Brasilichnium elusivum for the following characters: digit marks II and III

Table 2. From left to right, (Rep. $\mathrm{N}^{\circ}$ ): repository numbers. (Trackway): when necessary (i.e., multiple trackways on the same slab), each trackway is labelled with a letter (e.g., URCM.41-A). (Footprint $\mathrm{N}^{\circ}$ ): number of pes mark in the trackway. (Foot L): pes length, and (Foot $\mathrm{W})$ : width $(\mathrm{mm})$. (Digits $\mathrm{Y} / \mathrm{N})$ : presence (yes: $\mathrm{Y}$ ) or absence (not: $\mathrm{N}$ ) of digit marks on the footprint. ( $\mathrm{N}^{\circ}$ of digit - Pes): number of visible digit marks on the foot mark. (Pes Rotation): orientation of the longitudinal axis of the pes respect to the trackway midline; rotation is expressed in qualitative terms: 0 (zero) = no rotation, 1 (one) $=$ inward rotation of pes. (Handprint $-\mathrm{Y} / \mathrm{N})$ : presence $(\mathrm{Y})$ or absence $(\mathrm{N})$ of the handmark on a given step. (Manus L): manus length and (Manus W) width in $\mathrm{mm}$. ( $\mathrm{N}^{\circ}$ of digits - Manus): number of visible digit marks on the handprint. Asterisk for the holotype (URCR.70).

\begin{tabular}{|c|c|c|c|c|c|c|c|c|c|c|c|}
\hline Rep. No. & Trackway & $\begin{array}{c}\text { Footprint } \\
\text { No. }\end{array}$ & $\begin{array}{c}\text { Foot } \\
\mathrm{L}\end{array}$ & $\begin{array}{c}\text { Foot } \\
\text { W }\end{array}$ & $\begin{array}{l}\text { Digits } \\
(\mathrm{Y} / \mathrm{N})\end{array}$ & $\begin{array}{c}\text { No. of } \\
\text { digit (Pes) }\end{array}$ & $\begin{array}{c}\text { Pes } \\
\text { Rotation }\end{array}$ & $\begin{array}{l}\text { Handprint } \\
(\mathrm{Y} / \mathrm{N})\end{array}$ & $\begin{array}{c}\text { Manus } \\
\mathrm{L}\end{array}$ & $\begin{array}{c}\text { Manus } \\
\text { W }\end{array}$ & $\begin{array}{c}\text { No. of } \\
\text { digits (Manus) }\end{array}$ \\
\hline \multirow[t]{5}{*}{ URCM.41 } & $A$ & 1 & 44 & $\mathrm{n} / \mathrm{a}$ & $\mathrm{N}$ & $\mathrm{n} / \mathrm{a}$ & $\mathrm{n} / \mathrm{a}$ & $\mathrm{N}$ & $\mathrm{n} / \mathrm{a}$ & $\mathrm{n} / \mathrm{a}$ & $\mathrm{n} / \mathrm{a}$ \\
\hline & & 2 & 34 & 57 & $\mathrm{~N}$ & $\mathrm{n} / \mathrm{a}$ & $\mathrm{n} / \mathrm{a}$ & $\mathrm{N}$ & $\mathrm{n} / \mathrm{a}$ & $\mathrm{n} / \mathrm{a}$ & $\mathrm{n} / \mathrm{a}$ \\
\hline & & 3 & 39 & 57 & $\mathrm{~N}$ & $\mathrm{n} / \mathrm{a}$ & $\mathrm{n} / \mathrm{a}$ & $\mathrm{N}$ & $\mathrm{n} / \mathrm{a}$ & $\mathrm{n} / \mathrm{a}$ & $\mathrm{n} / \mathrm{a}$ \\
\hline & & 4 & 33 & 54 & $\mathrm{~N}$ & $\mathrm{n} / \mathrm{a}$ & $\mathrm{n} / \mathrm{a}$ & $\mathrm{N}$ & $\mathrm{n} / \mathrm{a}$ & $\mathrm{n} / \mathrm{a}$ & $\mathrm{n} / \mathrm{a}$ \\
\hline & & 5 & 44 & 59 & $Y$ & 4 & $\mathrm{n} / \mathrm{a}$ & $\mathrm{N}$ & $\mathrm{n} / \mathrm{a}$ & $\mathrm{n} / \mathrm{a}$ & $\mathrm{n} / \mathrm{a}$ \\
\hline \multirow[t]{12}{*}{ URCR.70* } & $\mathrm{n} / \mathrm{a}$ & 0 & $\mathrm{n} / \mathrm{a}$ & $\mathrm{n} / \mathrm{a}$ & $\mathrm{n} / \mathrm{a}$ & $\mathrm{n} / \mathrm{a}$ & $\mathrm{n} / \mathrm{a}$ & $Y$ & $\mathrm{n} / \mathrm{a}$ & 28 & 2 \\
\hline & & 1 & 46 & 62 & Y & 4 & 0 & $Y$ & $\mathrm{n} / \mathrm{a}$ & 16 & 2 \\
\hline & & 2 & 42 & 60 & $Y$ & 4 & 1 & $Y$ & $\mathrm{n} / \mathrm{a}$ & 25 & 2 \\
\hline & & 3 & 46 & 62 & $Y$ & 4 & 0 & $Y$ & $\mathrm{n} / \mathrm{a}$ & 20 & 2 \\
\hline & & 4 & 41 & 60 & $Y$ & 4 & 1 & $Y$ & $\mathrm{n} / \mathrm{a}$ & 28 & 2 \\
\hline & & 5 & 42 & 59 & $Y$ & 4 & 0 & $Y$ & $\mathrm{n} / \mathrm{a}$ & 22 & 2 \\
\hline & & 6 & 41 & 60 & $Y$ & 4 & 1 & $Y$ & $\mathrm{n} / \mathrm{a}$ & 23 & 2 \\
\hline & & 7 & 43 & 59 & $Y$ & 4 & 0 & $Y$ & $\mathrm{n} / \mathrm{a}$ & 12 & 2 \\
\hline & & 8 & 40 & 56 & $Y$ & 4 & 1 & $Y$ & $n / a$ & 24 & 2 \\
\hline & & 9 & 40 & 57 & $Y$ & 4 & 0 & $Y$ & $\mathrm{n} / \mathrm{a}$ & 17 & 2 \\
\hline & & 10 & 41 & 60 & $Y$ & 4 & 1 & $Y$ & $\mathrm{n} / \mathrm{a}$ & $\mathrm{n} / \mathrm{a}$ & 2 \\
\hline & & 11 & 43 & 58 & $Y$ & 4 & 0 & $Y$ & $\mathrm{n} / \mathrm{a}$ & 28 & 2 \\
\hline \multirow[t]{7}{*}{ URCR.110 } & $\mathrm{n} / \mathrm{a}$ & 1 & $\mathrm{n} / \mathrm{a}$ & 63 & $Y$ & 4 & 1 & $\mathrm{~N}$ & $\mathrm{n} / \mathrm{a}$ & $\mathrm{n} / \mathrm{a}$ & $\mathrm{n} / \mathrm{a}$ \\
\hline & & 2 & 47 & 63 & $Y$ & 4 & 1 & $\mathrm{~N}$ & $\mathrm{n} / \mathrm{a}$ & $\mathrm{n} / \mathrm{a}$ & $\mathrm{n} / \mathrm{a}$ \\
\hline & & 3 & 49 & 60 & $Y$ & 4 & 1 & $Y$ & $\mathrm{n} / \mathrm{a}$ & $\mathrm{n} / \mathrm{a}$ & 2 \\
\hline & & 4 & 48 & 58 & $Y$ & 4 & 1 & $\mathrm{~N}$ & $\mathrm{n} / \mathrm{a}$ & $\mathrm{n} / \mathrm{a}$ & $\mathrm{n} / \mathrm{a}$ \\
\hline & & 5 & 45 & 61 & $Y$ & 4 & 1 & $Y$ & $\mathrm{n} / \mathrm{a}$ & $\mathrm{n} / \mathrm{a}$ & 2 \\
\hline & & 6 & 47 & 62 & $\mathrm{Y}$ & 4 & 1 & $\mathrm{~N}$ & $n / a$ & $\mathrm{n} / \mathrm{a}$ & $\mathrm{n} / \mathrm{a}$ \\
\hline & & 7 & $\mathrm{n} / \mathrm{a}$ & $\mathrm{n} / \mathrm{a}$ & $\mathrm{n} / \mathrm{a}$ & $\mathrm{n} / \mathrm{a}$ & $\mathrm{n} / \mathrm{a}$ & $\mathrm{n} / \mathrm{a}$ & $\mathrm{n} / \mathrm{a}$ & $\mathrm{n} / \mathrm{a}$ & $\mathrm{n} / \mathrm{a}$ \\
\hline \multirow[t]{4}{*}{ URCR.111 } & $\mathrm{n} / \mathrm{a}$ & 1 & 46 & 64 & $Y$ & 4 & 1 & $\mathrm{Y}$ & 8 & 23 & 2 \\
\hline & & 2 & 47 & 58 & $Y$ & 4 & 1 & $\mathrm{~N}$ & $\mathrm{n} / \mathrm{a}$ & $\mathrm{n} / \mathrm{a}$ & $\mathrm{n} / \mathrm{a}$ \\
\hline & & 3 & 42 & 64 & $Y$ & 4 & 1 & $Y$ & 8 & 23 & 2 \\
\hline & & 4 & 40 & 56 & $Y$ & 4 & 1 & $\mathrm{~N}$ & $\mathrm{n} / \mathrm{a}$ & $\mathrm{n} / \mathrm{a}$ & $\mathrm{n} / \mathrm{a}$ \\
\hline \multirow[t]{3}{*}{ URCR.112 } & $\mathrm{n} / \mathrm{a}$ & 1 & 45 & 68 & $\mathrm{~N}$ & $\mathrm{n} / \mathrm{a}$ & $\mathrm{n} / \mathrm{a}$ & $Y$ & $\mathrm{n} / \mathrm{a}$ & $\mathrm{n} / \mathrm{a}$ & $\mathrm{n} / \mathrm{a}$ \\
\hline & & 2 & 44 & 67 & $\mathrm{~N}$ & $\mathrm{n} / \mathrm{a}$ & $\mathrm{n} / \mathrm{a}$ & $\mathrm{N}$ & $\mathrm{n} / \mathrm{a}$ & $\mathrm{n} / \mathrm{a}$ & $\mathrm{n} / \mathrm{a}$ \\
\hline & & 3 & 47 & 61 & $\mathrm{~N}$ & $\mathrm{n} / \mathrm{a}$ & $\mathrm{n} / \mathrm{a}$ & $Y$ & $n / a$ & $\mathrm{n} / \mathrm{a}$ & $\mathrm{n} / \mathrm{a}$ \\
\hline \multirow[t]{4}{*}{ URCR.115 } & $\mathrm{n} / \mathrm{a}$ & 1 & 43 & $\mathrm{n} / \mathrm{a}$ & $\mathrm{N}$ & $\mathrm{n} / \mathrm{a}$ & 1 & $\mathrm{~N}$ & $\mathrm{n} / \mathrm{a}$ & $\mathrm{n} / \mathrm{a}$ & $\mathrm{n} / \mathrm{a}$ \\
\hline & & 2 & 58 & 70 & $\mathrm{~N}$ & $\mathrm{n} / \mathrm{a}$ & 0 & $Y$ & 10 & 24 & $? 3$ \\
\hline & & 3 & 47 & 68 & $\mathrm{~N}$ & $\mathrm{n} / \mathrm{a}$ & 1 & $\mathrm{~N}$ & $n / a$ & $n / a$ & $\mathrm{n} / \mathrm{a}$ \\
\hline & & 4 & 61 & 73 & $\mathrm{~N}$ & $\mathrm{n} / \mathrm{a}$ & 0 & $\mathrm{~N}$ & $n / a$ & $\mathrm{n} / \mathrm{a}$ & $\mathrm{n} / \mathrm{a}$ \\
\hline \multirow[t]{2}{*}{ URCR.138 } & $\mathrm{n} / \mathrm{a}$ & 1 & 43 & 61 & $\mathrm{~N}$ & $\mathrm{n} / \mathrm{a}$ & $\mathrm{n} / \mathrm{a}$ & $\mathrm{N}$ & $n / a$ & $\mathrm{n} / \mathrm{a}$ & $\mathrm{n} / \mathrm{a}$ \\
\hline & & 2 & 43 & 69 & $\mathrm{~N}$ & $\mathrm{n} / \mathrm{a}$ & $\mathrm{n} / \mathrm{a}$ & $\mathrm{N}$ & $\mathrm{n} / \mathrm{a}$ & $\mathrm{n} / \mathrm{a}$ & $\mathrm{n} / \mathrm{a}$ \\
\hline \multirow[t]{5}{*}{ URCR.142 } & $\mathrm{n} / \mathrm{a}$ & 1 & 56 & $\mathrm{n} / \mathrm{a}$ & $\mathrm{N}$ & $\mathrm{n} / \mathrm{a}$ & $\mathrm{n} / \mathrm{a}$ & $\mathrm{N}$ & $\mathrm{n} / \mathrm{a}$ & $\mathrm{n} / \mathrm{a}$ & $\mathrm{n} / \mathrm{a}$ \\
\hline & & 2 & 43 & 59 & $\mathrm{~N}$ & $\mathrm{n} / \mathrm{a}$ & $\mathrm{n} / \mathrm{a}$ & $\mathrm{N}$ & $\mathrm{n} / \mathrm{a}$ & $\mathrm{n} / \mathrm{a}$ & $\mathrm{n} / \mathrm{a}$ \\
\hline & & 3 & 49 & 62 & $\mathrm{~N}$ & $\mathrm{n} / \mathrm{a}$ & $\mathrm{n} / \mathrm{a}$ & $Y$ & $\mathrm{n} / \mathrm{a}$ & $\mathrm{n} / \mathrm{a}$ & $\mathrm{n} / \mathrm{a}$ \\
\hline & & 4 & 45 & 72 & $\mathrm{~N}$ & $\mathrm{n} / \mathrm{a}$ & $\mathrm{n} / \mathrm{a}$ & $\mathrm{N}$ & $\mathrm{n} / \mathrm{a}$ & $\mathrm{n} / \mathrm{a}$ & $\mathrm{n} / \mathrm{a}$ \\
\hline & & 5 & $\mathrm{n} / \mathrm{a}$ & $\mathrm{n} / \mathrm{a}$ & $\mathrm{N}$ & $\mathrm{n} / \mathrm{a}$ & $\mathrm{n} / \mathrm{a}$ & $\mathrm{N}$ & $\mathrm{n} / \mathrm{a}$ & $\mathrm{n} / \mathrm{a}$ & $\mathrm{n} / \mathrm{a}$ \\
\hline
\end{tabular}


Table 3. From left to right, (Rep. $\left.\mathrm{N}^{\circ}\right)$ : repository numbers. (Trackway): when necessary (i.e., multiple trackways on the same slab), each trackway is labelled with a letter (e.g., URCM.41-A). (Pes Pace): number of pes pace and measure (mm). (Pes Stride): stride and relative measure ( $\mathrm{mm}$ ). (Pes Triplet): in this column, the triplet of footprints is reported on which pace angulation has been measured (in degrees). The same measurements are repeated for the handprints from ninth column on.

\begin{tabular}{|c|c|c|c|c|c|c|c|c|c|c|c|c|c|c|c|}
\hline Rep. No. & Trackway & $\begin{array}{l}\text { Pes } \\
\text { Pace }\end{array}$ & $\mathrm{mm}$ & $\begin{array}{l}\text { Pes } \\
\text { Stride }\end{array}$ & $\mathrm{mm}$ & $\begin{array}{l}\text { Pes } \\
\text { triplet }\end{array}$ & degrees & $\begin{array}{c}\text { Manus } \\
\text { Pace }\end{array}$ & $\mathrm{mm}$ & $\begin{array}{l}\text { Manus } \\
\text { Stride }\end{array}$ & $\mathrm{mm}$ & $\begin{array}{c}\text { Manus } \\
\text { triplet }\end{array}$ & degrees & $\begin{array}{l}\text { Pes-Manus } \\
\text { Distance }\end{array}$ & $M m$ \\
\hline \multirow[t]{4}{*}{ URCM.41 } & A & 1_2 & 170 & 1_3 & 265 & 123 & 119 & 1 & 1 & 1 & 1 & 1 & 1 & 1 & 1 \\
\hline & & $2 \_3$ & 140 & $2 \_4$ & 271 & 234 & 123 & 1 & 1 & 1 & 1 & 1 & 1 & 1 & 1 \\
\hline & & 3_4 & 175 & 3_5 & 264 & 345 & 122 & 1 & 1 & 1 & 1 & 1 & 1 & 1 & 1 \\
\hline & & $4 \_5$ & 128 & 1 & 1 & 1 & 1 & 1 & 1 & 1 & 1 & 1 & 1 & 1 & 1 \\
\hline \multirow[t]{10}{*}{ URCR.70* } & $\mathrm{n} / \mathrm{a}$ & $1 \_2$ & 126 & $1 \_3$ & 172 & 123 & 102 & $0 \_1$ & 123 & $0 \_2$ & 173 & zero12 & 85 & 1_1a & 32 \\
\hline & & $2 \_3$ & 95 & 2_4 & 175 & 234 & 104 & 1_2 & 134 & 1_3 & 171 & 123 & 82 & 2_2a & 13 \\
\hline & & 3_4 & 127 & 3_5 & 173 & 345 & 103 & 2_3 & 126 & 2_4 & 174 & 234 & 83 & 3_3a & 22 \\
\hline & & $4 \_5$ & 93 & $4 \_6$ & 168 & 456 & 101 & 3_4 & 135 & 3_5 & 172 & 345 & 82 & 4_4a & 11 \\
\hline & & 5_6 & 125 & 5_7 & 167 & 567 & 102 & 4_5 & 130 & 4_6 & 174 & 456 & 81 & 5_5a & 39 \\
\hline & & $6 \_7$ & 89 & $6 \_8$ & 171 & 678 & 105 & $5 \_6$ & 133 & $5 \_7$ & 171 & 567 & 82 & 6_6a & 35 \\
\hline & & 7_8 & 126 & 7_9 & 171 & 789 & 104 & 6_7 & 122 & $6 \_8$ & 164 & 678 & 79 & 7_7a & 41 \\
\hline & & 8_9 & 90 & 8_10 & 160 & 8910 & 102 & 7_8 & 136 & 7_9 & 171 & 789 & 80 & 8_8a & 24 \\
\hline & & 9_10 & 115 & 9_11 & 170 & 91011 & 109 & 8_9 & 130 & 8_10 & 165 & 8910 & 79 & 9_9a & 44 \\
\hline & & $10 \_11$ & 95 & $\bar{\nearrow}$ & 1 & 1 & 1 & 9_10 & 132 & 9_11 & 161 & 91011 & 74 & 10_10a & 23 \\
\hline \multirow[t]{5}{*}{ URCR.110 } & $\mathrm{n} / \mathrm{a}$ & 1_2 & 105 & $1 \_3$ & 188 & 123 & 120 & 0 & 1 & $0 \_2$ & 190 & 1 & 1 & $\overline{1}$ & 1 \\
\hline & & $2 \_3$ & 111 & 2_4 & 184 & 234 & 115 & 1_2 & 1 & 1_3 & 194 & 1 & 1 & 1 & 1 \\
\hline & & 3_4 & 107 & 3_5 & 189 & 345 & 114 & $2 \_3$ & 1 & 2_4 & 1 & 1 & 1 & 1 & 1 \\
\hline & & $4 \_5$ & 117 & $4 \_6$ & 192 & 456 & 115 & 3_4 & 1 & 3_5 & 1 & 1 & 1 & 1 & 1 \\
\hline & & 5_6 & 111 & 1 & 1 & 1 & 1 & 1 & 1 & 1 & 1 & 1 & 1 & 1 & 1 \\
\hline \multirow[t]{3}{*}{ URCR.111 } & $\mathrm{n} / \mathrm{a}$ & $1 \_2$ & 107 & $1 \_3$ & 188 & 123 & 116 & 1 & 1 & $0 \_2$ & 190 & 1 & 1 & 1_1a & 30 \\
\hline & & 2_3 & 114 & 2_4 & 189 & 234 & 123 & 1 & 1 & 1 & 1 & 1 & 1 & 2_2a & 32 \\
\hline & & 3_4 & 102 & 3_5 & 1 & 1 & 1 & 1 & 1 & 1 & 1 & 1 & 1 & 1 & 1 \\
\hline \multirow[t]{3}{*}{ URCR.112 } & $\mathrm{n} / \mathrm{a}$ & 1_2 & 148 & 1_3 & 237 & 123 & 117 & 1_2 & 156 & 1_3 & 237 & 123 & 102 & 1_1a & 42 \\
\hline & & $2 \_3$ & 128 & 1 & 1 & 1 & 1 & $2 \_3$ & 130 & 1 & 1 & 1 & 1 & 2_2a & 47 \\
\hline & & 3_4 & $\backslash$ & 1 & 1 & 1 & 1 & 1 & 1 & 1 & 1 & 1 & 1 & 3_3a & 35 \\
\hline \multirow[t]{3}{*}{ URCR.115 } & $\mathrm{n} / \mathrm{a}$ & 1_2 & 116 & $1 \_3$ & 211 & 123 & 110 & 1 & 1 & 1 & 1 & 1 & 1 & 1_1a & 23 \\
\hline & & $2 \_3$ & 141 & $2 \_4$ & 226 & 234 & 117 & 1 & 1 & 1 & 1 & 1 & 1 & 1 & 1 \\
\hline & & 3_4 & 123 & 1 & 1 & 1 & 1 & 1 & 1 & 1 & 1 & 1 & 1 & 1 & 1 \\
\hline
\end{tabular}

are functionally dominant for load bearing in B. anaiti, respect to those in B. elusivum. The overall pes shape is more symmetrical in B. anaiti than in B. elusivum, with a coarse bilateral symmetry respect to a plane passing between digit marks II and III. Central digit marks in $B$. anaiti commonly show divergent distal ends. In B. elusivum digit marks I-III are usually iso-oriented. Pes digit mark in $B$. anaiti are more neatly isolated from the sole mark than in B. elusivum, with a drop-like shape of central digit mark II and III. The average size of $B$. anaiti is four times bigger than that of B. elusivum.

Description: All slabs at the Rio Claro Collection preserve trackways of animals moving uphill, in walking gait. The direction of the trackways is inferred from the relative orientation of the expulsion rims and digit marks. Five out of eight trails are preserved as concave epirelief (URCR.70; URCR.110; URCR.111; URCR.112; URCR.138), the remaining three trackways are preserved as convex hyporelief (URCR.115; URCR.142; URCM.41).

When preserved, all pes prints show four digit marks. There is no unequivocal way to refer these digit marks to trackmaker's acropodials (digits I, II, III, and IV, or digits II, III, IV, and V, alternatively). The general shape of the footmark is symmetric, although digit mark I is apparently shorter than digit mark IV. Digit marks II and III are usually the best preserved in the series, and have approximately the same length. Digit mark IV is stouter than the others (Fig. 4). The sole mark mostly represents the metatarsal-phalangeal portion of the autopodium region, and is the portion of maximum penetration of the pes into the substrate, anteriorly; it fades rapidly into the anterior wall of the expulsion rim, posteriorly. The sole mark is roughly elliptical, wider than long.

The longitudinal axis of the pes is frequently rotated inward, so that the lateral digit mark extends far anterior to the tip of the medial digit. Digit marks may appear straight or, in several cases, outward oriented. This latter case seems related to the recurrent rotation of the autopodium during the walk cycle. Footprints are usually shallow, but deeper traces are occasionally preserved. Tracks of one side of the trail may be rotated to a different degree in relation to the controlateral series, so that the trackway results asymmetric relative to the midline.

Manus prints are relatively rare, except on URCR.70, where manus prints outnumber pes prints. Hand traces are typically shallower than those of the foot, and their preservation is usually worse, to the point that is difficult to define a clear pattern. It is common to find two to three faint marks left by hand digits (Fig. 5). It is unclear if the faintness of the hand prints is the effect of a digitigrade posture or a taphonomic bias, but we tend to support the latter 


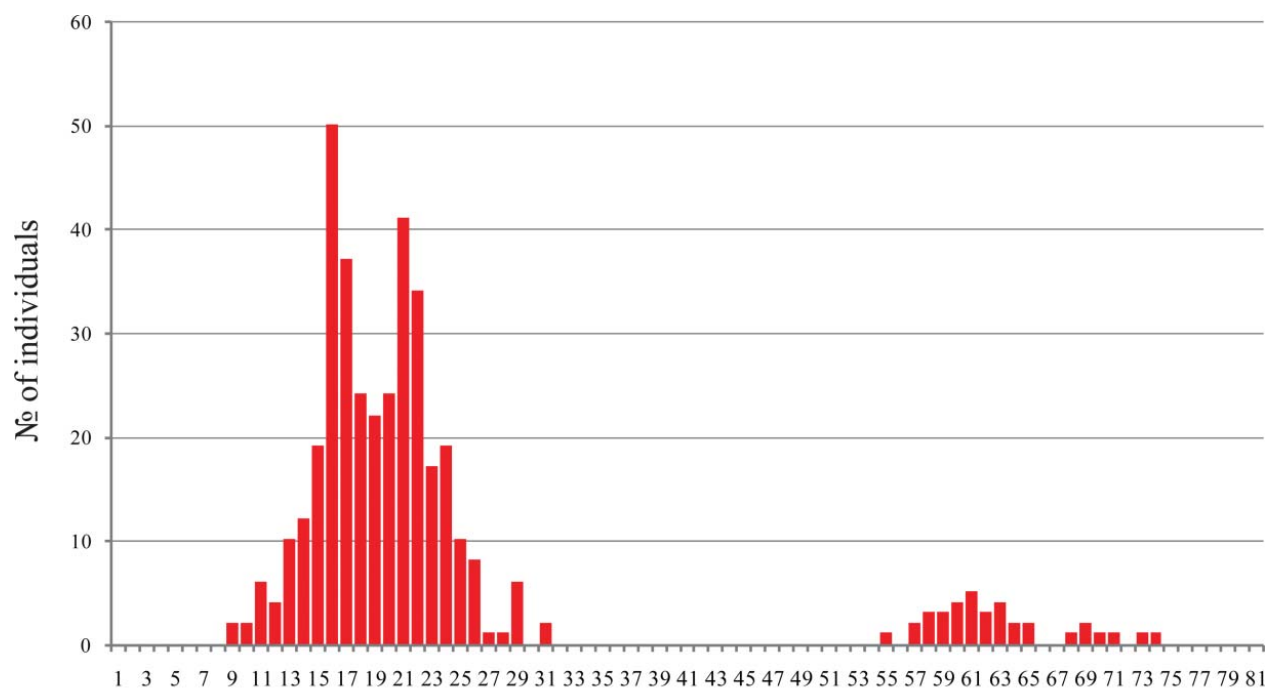

FW (mm)

Figure 6. Frequency distribution as plotted from the Rio Claro dataset. Footprint width (FW) on the $\mathrm{X}$ axis (in mm); number of individuals on the $Y$ axis. From left to right, Brasilichnium elusivum $(n=351)$ and B. anaiti $(n=36)$. Difference in height is due to the high number of individuals for $B$. elusivum in the sample respect to those of $B$. anaiti. Note the clear dimensional gap between the two groups.

explanation (see below). From a quantitative point of view, the footprint length (FL) has a mean value of $44.58 \mathrm{~mm}$, whereas the mean for foot width (FW) is $61.64 \mathrm{~mm}$. The mode for FW is $60 \mathrm{~mm}$. Manus traces have an average length of $8.67 \mathrm{~mm}$ for a width of $22.35 \mathrm{~mm}$. Trackways show an average foot stride of $196.71 \mathrm{~mm}$, whereas pes pace angulation is 111.57 degrees on average. Manus stride is $179 \mathrm{~mm}$ on average, for a pace angulation mean value of 82.63 degrees. Manus-pes distance is $31.35 \mathrm{~mm}$ on average. Trackway width has an average value of $145.8 \mathrm{~mm}$.

A complete dataset of measurements is seen in Tables 1-3. When indexed to the average width of the pes, which is the most consistent linear measurement, we find that the trackway width is 2.36 times the foot width; stride/pes width ratio is 3.19 .

\section{Discussion and remarks}

Fernandes and Carvalho (2008) redefined to four the number of digit marks on the pes of Brasilichnium elusivum. This shows that the material under examination and $B$. elusivum share a similar basic pedal structure. The analysis of specimens of B. elusivum at the Rio Claro collection (D'Orazi Porchetti et al., 2016) reveals more shared features with $B$. anaiti.

Based on the examined sample, the FL/FW ratio of Brasilichnium anaiti is 0.72 ( $\mathrm{FL} \mathrm{n}=38$, $\mathrm{FW} \mathrm{n}=36$ ), a value remarkably similar to that of B. elusivum (FL/FW ratio $=0.69$ ), as calculated on best preserved tracks (FL $\mathrm{n}=313$; FW $\mathrm{n}=351$ ) from a total sample of 420 pes prints of $B$. elusivum in walking gait. At the same time, a comparison of the mean values of foot width between
B. elusivum and $B$. anaiti reveals a clear dimensional gap (Fig. 6). The mode for the FW value of B. elusivum (based on the Rio Claro sample) is $15 \mathrm{~mm}$, compared to a $60 \mathrm{~mm}$ value in $B$. anaiti. In addition, the minimum value of foot width in $B$. anaiti is $54 \mathrm{~mm}$, for a maximum of $73 \mathrm{~mm}$, whereas the maximum value measured for B. elusivum, in the Rio Claro collection, is $30 \mathrm{~mm}$ (minimum $=8 \mathrm{~mm}$ ). Accordingly, there is no overlapping between the footprint sizes of small and large Brasilichnium, even at the extremes of their dimensional distribution, and the comparison between the modes of FW values for B. elusivum and B. anaiti $(15 \mathrm{~mm}$ vs. $60 \mathrm{~mm}$ ) definitively split these two forms apart from one another.

The adoption of a new ichnotaxonomic label, especially at the ichnospecies rank, is particularly prone to the author's view in naming practices. Recommendation in the adoption of ichnotaxobases (see Bertling, 2007; Bertling et al., 2006), suggest to avoid size as a diagnostic feature. However, when associated to other morphologic features, as with the material under examination, size might give helpful insights. Differences in morphology, associated to the neat dimensional gap between these two morphotypes, and the variable locomotion styles of Brasilichnium elusivum (see D'Orazi Porchetti et al., 2017), in contrast to the single walking gait observed in B. anaiti, justify a separation at least at the ichnospecific level (Fig. 7).

Relative abundance has been calculated on the slab sample of the Rio Claro Collection. On a total of 109 slabs, eight yielded material ascribable to the new ichnotaxon. In terms of number of trackways, the comparison 


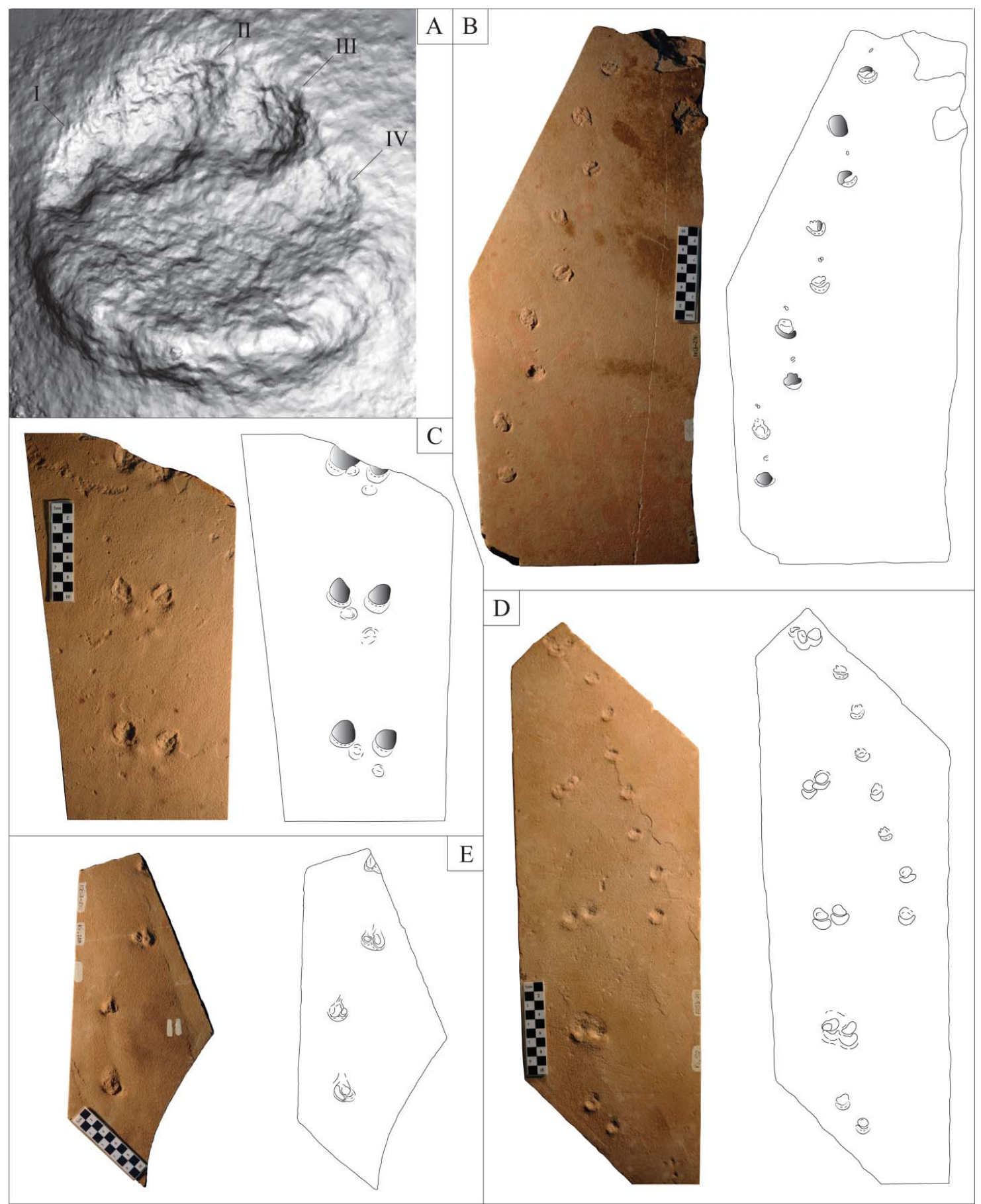

Figure 7. Selected specimens from the Rio Claro Collection, reproduced here in order to show foot morphology and gaits of Brasilichnium elusivum. A. Three-dimensional model of a single footprint from slab URCM.41, to show details of the pes morphology of Brasilichnium elusivum. Original track preserved as convex hyporelief. Track width $2 \mathrm{~cm}$. B. Photograph and drawing of slab URCM.34; slab with well-preserved trackways in walking gait with manus prints; scale bar $10 \mathrm{~cm}$. Drawing at the same scale of the photograph. All footprints preserved as convex hyporelief. C. Brasilichnium elusivum, photograph and drawing of slab URCR.23, with three consecutive manus-pes sets in half-bounding gait, preserved as convex hyporelief. The trackway is heading to the top of the image. Pes prints are incomplete, partially lost at their top (shaded gray). Scale bar $10 \mathrm{~cm}$. D. Photograph and drawing of slab URCM. 52 with B. elusivum trackway in skipping gait (on the left side of the slab). Scale bar $10 \mathrm{~cm}$. Drawing at the same scale of the photograph. All tracks preserved as concave epirelief. E. Photograph and drawing of slab URCM.113 with downhill-oriented trackway of B. elusivum. The trackmaker was moving from the top to the bottom of the slab. Scale bar $10 \mathrm{~cm}$. Drawing at the same scale of the photograph; footprints preserved as convex hyporelief. 
of $B$. elusivum/B. anaiti reveals a ratio of 89 to 8 , the larger quadrupedal traces being a tenth in number of those of B. elusivum, and $7.3 \%$ on the total number of slabs containing either of the morphotypes. Large and small Brasilichnium forms should not be regarded as the expression of the same trackmaker population not only because there is a discontinuity in size distribution, but also because $B$. elusivum shows an array of gaits which is unknown for B. anaiti.

As all the Botucatu ichnites are preserved on the foreset of sand dunes, they were all imprinted on inclined surfaces. Leonardi (1980) reported an average value, from measurements on 58 dune foresets, of 26 degrees (lowest $=12^{\circ}$; highest $=32^{\circ}$ ). Aside from other taphonomic aspects, an important feature, always associated with the foot mark, is an expulsion rim, which constantly rests on the downhill side of the track. Direct and indirect track features (sensu Gatesy, 2003) are sometimes so intimately associated to one another that is somewhat artificial to treat them separately. Yet marginal ridges bear no clear signs of the foot anatomy, but helps understanding how load forces acted on the sediment.

All the Rio Claro specimens have pressure pads, typically showing sediment displacement in a thrustlike fashion. These pressure pads are also asymmetric, when observed from behind. The medial portion is always shallower than the lateral one. If associated with the outward orientation of the pes digits, all these features can be explained as the effect of an inward rotation of the foot during the step cycle (D’Orazi Porchetti et al., 2014).

Another matter of discussion is whether the Botucatu tracks can be considered as surficial marks or the result of foot/sediment interaction at some depth below the surface. As remarkably shown by Loope (2006), tracks can be preserved even on dry sand, at a relative depth below the sediment/air interface. Several features on the Rio Claro footprints points to a subsurficial origin, and the preservational style of the hand prints might help explaining this point. As stated above, handprints are typically less well-preserved than pes prints in terms of anatomical completeness (preservation of only the distal portions of the digits) and quantity (manus traces present only on one side of the trackway or totally absent). The combined action of the inclined surface, which moves weight vectors back onto the rear legs, and possibly the biomechanics of the trackmakers (weight distribution on the forearms), allowed for a reduced penetration of the hand into the sediment (Seilacher, 2007). Accordingly the final contact of the pes and the manus happened at different depth into the sand on the lee side of the dunes. This explains why only the distal, digital portion of the hand is usually preserved. Thus the possibility to observe a clear hand mark in association with the footprint is usually hampered. Yet, it is not absolutely clear that all these traces are deep prints. As a consequence, there is no unambiguous way to state a clear dimensional ratio between the hand and the foot marks.

\section{Trackmaker attribution}

Previous works on the quadrupedal morphotypes of the Botucatu Formation relied on the presumed age of this lithostratigraphic unit to evaluate potential trackmakers. As a consequence, shift in dating affected the attribution. For instance, Leonardi et al. (2007) stated, in a recent reappraisal of the Botucatu ichnofauna, that the "theromorphoid" tracks might have been made by undetermined true mammals, on the basis of a reassessment of the age of the Botucatu Formation (Scherer, 2000; 2002). The process of trackmaker attribution should otherwise exclusively rely on features that are unequivocal expressions of trackmaker's morphological characters. Obviously, this approach has its own clear limits, as useful characters (i.e., synapomorphies) are rarely found in footprints.

In the original interpretation of Leonardi, the producer of the footprints discussed here was something different from that of Brasilichnium elusivum, for two reasons. In his understanding (Leonardi, 1980; Leonardi and Sarjeant, 1986), B. elusivum was pentadactyl and B. anaiti was too large for a Mesozoic mammal. However relatively large mammals are known today from the Early Cretaceous of China (i.e., Repenomamus giganticus Hu et al., 2005).

The phalangeal formula proposed by Leonardi (1981) for Brasilichnium elusivum (2-3-3-3-3) cannot be tested on the sampled footprints, as digit marks show only one pad. The number of four digit marks in the pes of $B$. anaiti is not indicative for any specific group, given that different lineages, other than synapsids, such as crocodylomorphs, have forms with tetradactyl feet.

Yet, Brasilichnium anaiti shows a discontinuity, which appears as a hiatus or a stenosis, in the proximal part of the phalangeal portion of the foot, best visible on the central couple of digit marks. This structure is seen in the form of a crease or groove, depending on the style of footprint preservation (concave epirelief or convex hyporelief), separating the sole print from digit marks. This feature can be useful for the attribution of $B$. anaiti as it is related to the configuration and posture of the acropodium. This mark is well explained by the presence of a digital arcade (Kümmel and Frey, 2012, 2014) in the foot, an arrangement that does not allow all phalanges to touch the sediment at the same level. In this acropodial 
configuration, digits are held bent in the sagittal plane during most part of the walking cycle.

Kümmel and Frey (2012) first presented evidence of a digital arcade in footprints of purported synapsid origin. Among others, a specimen of Brasilichnium elusivum is figured in Kümmel and Frey (2012, fig. 17f, from Lockley and Hunt 1995, fig. 4.22). As noted by Kümmel and Frey (2012, 2014), a digital arcade is present in most extant mammals as it was in most Therapsida, including Mesozoic Mammaliamorpha. Accordingly, we here adopt this feature as robust evidence for the mammaliamorph therapsid origin of $B$. anaiti.

A more comprehensive discussion about the trackmakers attribution of Brasilichnium anaiti is extremely problematic. Direct comparison with body fossils from similar environments, and comparable age, are hampered by the rarity of skeletal specimens preserving complete autopodia. If the temporal range of large and small Brasilichnium is considered as a whole, with a Late Triassic FAD from the Redonda Formation (Lucas et al., 2010) and an Early Cretaceous LAD from the Botucatu Formation (according to age attribution of Scherer 2000, 2002), a time span of approximately 75 MY (RethianValanginian) is found. During this period, Brasilichnium had its acme in the Early Jurassic of the Navajo Sandstone (and equivalents) and in the Brazilian Botucatu Formation.

In Brasilichnium, trackmaker's foot morphology appears to be stable over a long period of time, as is the locomotion styles, and the association with a specific environmental setting. This might be interpreted as a true biological signal, or might depend on major misunderstandings of the age of the footprint-bearing lithostratigraphic units (particularly the Botucatu Formation). A comparison based on the time range of Brasilichnium, and that of Mesozoic therapsids, shows that potential trackmakers might belong either to non-mammalian mammaliamorphs, or to early mammals. So far, no definitive feature observed on B. anaiti can help discriminate between these two groups.

\section{Comparison with similar ichnomorphs}

Large Brasilichnium are relatively rare worldwide, if compared to the smaller forms, commonly labeled as Brasilichnium elusivum. Materials that could potentially be referred to as Brasilichnium anaiti comes from the Nugget Sandstone (Early Jurassic) Idaho, USA, as the specimen (CU 179.122) figured in Lockley et al. (2011, fig. 5B). Lockley and Hunt (1995) figured another specimen (CU-MWC 183.6) that bears strong similarities with the Brazilian material. Ellenberger (1970, 1972, 1974, 1975) erected several ichnotaxa on material from the Elliot and Clarens formations of Lesotho. Problems related to Ellenberger's approach to ichnotaxonomy have been highlighted in previous works (Olsen and Galton, 1984; Lockley et al., 2004; Rainforth, 2003; D’Orazi Porchetti and Nicosia, 2007), and many ichnotaxa of purported synapsid origin, proposed by Ellenberger, are nomina nuda.

On the other hand, Ellenberger's work gives us a glimpse on the ichnological richness of the Stormberg Group of Lesotho. Aside from stating the impelling need for revising the original material on its stratigraphic context, we can here attempt to identify the forms that bear closer similarities with Brasilichnium. Among them, ichnites with tetradactyl pes prints, from the $\mathrm{B} / 1$ zone of Ellenberger biostratigraphic framework, have been informally labeled as "Eotetrapodiscidés." Two ichnospecies, Eotetrapodiscus cursor and Eotetrapodiscus moyenensis, might be compared to the Brazilian material. E. cursor is apparently closer in size to the dimensional range of $\mathrm{Bra}$ silichnium anaiti. On the other hand, E. moyenensis is well beyond the size range of that ichnospecies.

Chelichnus is a Permian ichnogenus with four ichnospecies from North America and Europe (McKeever and Haubold, 1996), which bears coarse similarities with $\mathrm{Bra}$ silichnium. On the other hand, it is diagnosed as a pentadactyl (manus and pes) ichnotaxon, and therefore with a basic difference relative to Brasilichnium.

A general overview of possible synapsid tracks from similar environments should also take Navahopus into account, a quadrupedal ichnotaxon with two ichnospecies: N. falcipollex Baird (1980), and N. coyoteensis (Milan, Loope, and Bromley, 2008), both from the Lower Jurassic Navajo Sandstone of the United States. Lockley and Hunt (1995) discussed extensively on the subject, noting the similarity between Navahopus and Brasilichnium. Lockley et al. (1994) first proposed a synapsid origin for N. falcipollex. Hunt and Lucas (2006) reevaluated its holotype (MNAV 3430), pointing out incongruences in the composite outline proposed by Baird (1980). Discussing the ichnotaxonomic status of Navahopus is beyond the scope of the present paper, but Brasilichnium and Navahopus share important features, which points to a similar trackmaker. Footmarks of both forms have four digit marks, which are separated from the plantar portion of the footprints by a sand crease. This feature is here considered the result of the posture (digital arcade) of the trackmaker foot, which according to Kümmel and Frey $(2012,2014)$, indicate a therapsid origin. This similarity is of interest for the ichnological characterization of hyperarid environments, dominated by erg facies, and consequently for the Brasilichnium ichnocoenosis (Hunt and Lucas, 2007), especially under the paleozoological respects (see below). 


\section{Overview on the Botucatu ichnofaunal composition}

Leonardi and Oliveira (1990) first investigated the faunal composition of the Botucatu Formation on a quantitative basis. On a sample of 100 slabs (for a total count of 104 "individuals") from the Ouro site (slab ARSB-5 to slab ARSB-149; Leonardi and Oliveira, 1990, p. 227), they obtained the following percentages in terms of individual occurrences: mammaloid $=64.4 \%$, dinosauroid $=27.9 \%$, theromorphoid $=7.7 \%$. Our analysis is based on 109 slabs from the same locality. Of those, eight slabs (7.3\%) yielded theromorphoid (i.e., Brasilichnium anaiti) tracks. Mammaloids are represented on $61.5 \%$ of the slabs, and dinosauroids on $20.2 \%$. When the same sample is investigated for relative presence of individuals (to say, how many trackways of one form are present in the sample), we found that of the 154 recognized trackways, 90 are mammaloid $(58.4 \%), 22$ dinosauroid (14.3\%), and 8 theromorphoid (5.2\%). We considered 34 trackways as indeterminate, which represent $22.1 \%$ of the sample. Our results do not exactly match those of Leonardi and Oliveira (1990), although there are some similarities. The high percentage of forms that we do not ascribe to any category might influence the results, but the percentage of theromorphoid seems quite stable across the analyses. The Botucatu vertebrate ichnites composition also approaches that published by Reynolds (2006; Reynolds and Weasma, 2002) for the early Middle Jurassic Aztec Sandstone (but see Hunt and Lucas, 2006, for alternative dating of this lithostratigrphic unit), which has up to $70 \%$ of quadruped tracks and $30 \%$ of biped tracks. Similarly, Rainforth's (1997) report on the ichnofauna composition of the dunes foreset of the Navajo Sandstone shows that about $60 \%$ of the ichnotaxa can be ascribed to synapsid trackmakers, the remaining being of dinosaurian origin.

Aside from vertebrate tracks, the Botucatu slabs yielded an array of invertebrate ichnofossils. Leonardi (1980) first noticed the presence of worm and arthropod trails and burrows. A detailed study on the invertebrate ichnofauna of the Botucatu Formation (Fernandes et al., 1990) identified Taenidium satanassi and T. serpentinum, besides generic "U-shaped" burrows. The Rio Claro Collection includes invertebrate traces, as Planolites isp., Arenicolites isp., and at least one portion of arthropod trail (Plate II, slab URCR.138). These come from similar hyperarid depositional environments. On the other hand, the ichnological composition of the Botucatu Formation, as recorded from extensive sample of the Ouro site, is limited to dune foresets. So far, there is no interdune sampling, what may explain the abundance of relatively small tracks ( $<10$ centimeters in width), compared to the exiguous record of large forms, such as the alleged ornithopod tracks (MPA-334 and MPA-337 series I-V) described by Fernandes and Carvalho (2007), and some undetermined large tridactyl footprints (e.g., slab URCR.143) in the Rio Claro Collection.

Even if the validity of the land-vertebrate ichnofacies has been considered as problematic (Santi and Nicosia, 2008) or even refused (MacEachern et al., 2012), the attempt to formalize the recurrence of typical land-vertebrate footprints in specific depositional environments has a history, and should not be overlooked. Depending on the approach to the problem, the Octopodichnus-Entradichnus ichnofacies (Buatois and Mangáno, 2011) might be considered the most inclusive name to adopt in this case, with its parallel in the land-vertebrate ichnofacies represented by the Brasilichnium ichnocoenosis of the Chelichnus ichnofacies (Hunt and Lucas, 2007). In this regard, Hunt and Lucas (2007 and references therein) pointed out how the approach of vertebrate ichnologists to ichnofacies is more biotaxonomic than ethological. Before downgrading or dismissing land-vertebrate ichnofacies it would be important to evaluate ecologic aspects which are inherent to the recurrent association of specific ichnites and depositional environments, as in the case of Brasilichnium and paleoergs. In this respect, the basic approach is a strict process of definition based on the ichnotaxonomic composition. Formalization of a characteristic element of the Brasilichnium ichnocoenosis goes in this direction.

\section{Conclusions}

The Botucatu Formation slabs investigated in the present article revealed a distinct track morphotype, whose identity is substantiated by quantitative and qualitative data. For this reasons a new ichnospecies, Brasilichnium anaiti, is proposed to encompass this form. This new ichnotaxon is a useful tool in the frame of the ichnofacies approach to vertebrate ichnology, especially for the $\mathrm{Bra}$ silichnium ichnocoenosis of the Chelichnus ichnofacies (Hunt and Lucas, 2007), as it commonly appear associated to B. elusivum on the foreset of Mesozoic sand dunes. In percentage, dune foreset ichnocoenosis shows a constant ratio between therapsid and dinosaurian trackmakers, with a majority of the former group (relative abundance between 60 and $70 \%$ ).

The trackmaker of Brasilichnium anaiti is either a non-mammalian mammaliamorph, or an early mammal. Hyperarid facies, and specifically foresets of ancient sand dunes, shows a positive correlation with Mesozoic synapsid tracks, which are particularly abundant in this setting and shows a neat dimensional disparity, from very small to relatively large forms. 


\section{Acknowledgments}

This work is intended as a contribution for the project "Dune's Life: the Track Record of a Mesozoic Warm Desert." The University of São Paulo, at Ribeirão Preto, is acknowledged for support and logistics. We are indebted to Lilia Maria Dietrich Bertini for constant help and assistance. Cibele Gasparelo Voltani is kindly acknowledged for logistic support during collection analysis. We wish to thank Ignacio Díaz-Martínez (Universidad Nacional de Río Negro (Argentina) and an anonymous reviewer for helpful comments to the original manuscript. Lorenzo Marchetti (Università degli Studi di Padova) is acknowledged for further review. We would like to thank Hendrik Klein (Saurierwelt Paläontologisches Museum, Neumarkt) for constant editorial assistance.

\section{Funding}

S. D’Orazi Porchetti's research was supported by a Fundação de Amparo à Pesquisa do Estado de São Paulo (FAPESP) Post-Doctoral Grant (Process Number 2013/01930-1).

\section{ORCID}

Max C. Langer (iD http://orcid.org/0000-0003-1009-4605

\section{References}

Almeida, F. 1954. Botucatu, um deserto triássico da América do Sul. DNPM Divisão Geologia Mineralogia, Notas Preliminares Estudos, 86: 21 pp.

Assine, M. L., Piranha, J. M. and Carneiro, C. D. R. 2004. Os paleodesertos Pirambóia e Botucatu. In Mantesso-Neto, V., Bartorelli, A., Carneiro, C.D.R., and Brito-Neves, B.B. (eds.), Geologia do Continente Sul-Americano: evoluçáo da obra de Fernando Flávio Marques de Almeida. Beca Prod Cult Ltda, SP, Brasil. pp. 77-92.

Baird, D. 1980. A prosauropod dinosaur trackway from the Navajo Sandstone (Lower Jurassic) of Arizona. In Jacobs, L. L. (ed.), Aspects of Vertebrate History. Flagstaff, Museum of Northern Arizona Press, pp. 219-230.

Bertling, M. 2007. What's in a Name? Nomenclature, Systematics, Ichnotaxonomy. In Miller, W. (ed.), Trace Fossils: Concepts Problems and Prospects. Elsevier, Amsterdam, pp. 81-91.

Bertling, M., Braddy, S. J., Bromley, R. G., Demathieu, G. R., Genise, J., Mikuláš, R., Nielsen, J. K., Nielsen, K. S. S., Rindsberg, A. K., Schlirf, M., and Uchman, A. 2006. Names for trace fossils: A uniform approach. Lethaia, 39: 265-286.

Bonaparte, J. F. 1996. Late Jurassic vertebrate communities of eastern and western Gondwana. Georesearch Forum, 1-2: 427-432.

Bristow, C. and Mountney, N.P. 2013. Aeolian Stratigraphy. In Shroder, J. (ed.), Treatise on Geomorphology, 11, Elsevier, Amsterdam, pp. 246-268.

Brückmann, M., Hartmann, L. A., Tassinari, C. C. G., Sato, K., and Baggio, S. B. 2014. The duration of magmatism in the Serra Geral Group, Paraná volcanic province. In Hartmann, L.A., Sérgio, B., and Baggio, B. (eds.), Metallogeny and
Crustal Evolution of the Serra Geral Group. 1 ed. IGeo, Porto Alegre, Gráfica da UFRGS, pp. 507-518.

Buatois, L. A. and Mángano, M. G. 2011. Ichnology: Organism-Substrate Interactions in Space and Time. New York, Cambridge University Press, 358 pp.

D'Orazi Porchetti, S. and Nicosia, U. 2007. Re-examination of some large early Mesozoic tetrapod footprints from the African collection of Paul Ellenberger. Ichnos, 14: 219-245.

D'Orazi Porchetti, S. and Wagensommer, A. 2015. A vertebrate trackway from the Twyfelfontein Formation (Lower Cretaceous), Damaraland, Namibia. Paläontologische Zeitschrift 89: 807-814

D’Orazi Porchetti, S., Bertini, R.J., Langer, M.C. 2014. Microtectonic effects of quadrupedal footprints on the lee face of sand dunes from the Botucatu Formation (Lower Jurassic to Lower Cretaceous, Brazil): Possible interpretations. Journal of Vertebrate Paleontology, Program and Abstracts, 2014: pp. 121

D’Orazi Porchetti, S., Bertini, R. J., and Langer, M. C. 2017. Walking, running, hopping: Analysis of gait variability and locomotion styles in Brasilichnium elusivum Leonardi, and inferences on trackmaker identification. Paleogeograph, Paleoclimatology, Palaeoecology, 465: 14-29.

Ellenberger, P. 1970. Les niveaux paléontologiques de première apparition des Mammiferes primordiaux et leurichnologie: Establissement de zones stratigraphiques detaillees dans le Stormberg de Lesotho (Afrique du Sud) (Trias Superieur a Jurassique). Second Gondwana Sympospium, Proceedings and Papers, Council for Scientific and Industrial Research, Scientia, Pretoria, South Africa, pp. 343-370.

Ellenberger, P. 1972. Contribution à la classification des pistes de vertébrés du Trias: Lês types du Stormberg d'Afrique du Sud (I). Paleovertebrata, Mémoire Extraordinaire, 1972: 1-152.

Ellenberger, P. 1974. Contribution à la classification des pistes de Vertébrés du Trias: Lês types du Stormberg d'Afrique du Sud, 2e partie. Palaeovertebrata, Mémoire extraordinaire, Montpellier: $170 \mathrm{pp}$.

Ellenberger, P. 1975. L'explosion démographique dês petities quadrupèdes a allure de mammiferes dans le Stormberg Supérieur (Trias) d'Afrique du Sud a perçu sur leur origine au Permien (France et Karoo). Colloque International C.N. R.S. (1973), Problèmes Actueles de Paléontologie-Évolution des Vertébrés, 218: 409-432.

Falkingham, P. L. 2012. Acquisition of high resolution 3D models using free, open-source, photogrammetric software. Palaeontologia Electronica, 15, 1; 1T:15p; http://palaeo-elec tronica.org/content/93-issue-1-2012-technical-articles/923d-photogrammetry

Falkingham, P. L. 2016. Applying objective methods to subjective track outlines. In Falkingham, P.L., Marty, D., and Richter, A. (eds.), Dinosaur Tracks: The Next Step, Bloomington, IN, Indiana University Press, pp. 72-80.

Fernandes, A. C. S., Carvalho, I. S., and Netto, R. G. 1990. Icnofósseis de invertebrados na Formação Botucatu, São Paulo, Brasil. Anais da Academia Brasileira de Ciências, 62: $45-49$.

Fernandes, M. A. and Carvalho, I. S. 2007. Pegadas fósseis da Formação Botucatu (Jurássico Superior-Cretáceo Inferior). $O$ registro de um grande dinossauro Ornithopoda na Bacia do Paraná. In Carvalho, I.S. et al. (eds.), Paleontologia: Cenários da Vida, Editora Interciênca, Rio de Janeiro, pp. 425-432. 
Fernandes, M. A. and Carvalho, I. S. 2008. Revisão diagnóstica para a icnoespécie de tetrápode Mesozóico Brasilichnium elusivum (Leonardi, 1981) (Mammalia) da Formação Botucatu, Bacia do Paraná, Brasil. Ameghiniana, 45: 167-173.

Gatesy, S. 2003. Direct and indirect track features: What sediment did a dinosaur touch? Ichnos, 10: 91-98.

Hu, Y.-M., Meng, J., Wang, Y., and Li, C. 2005. Large Mesozoic mammals fed on young dinosaurs. Nature, 433: 149153.

Hunt, A. P. and Lucas, S. G. 2006. The Taxonomic status of Navahopus falcipollex and the Ichnofauna and Ichnofacies of the Navajo Lithosome (Lower Jurassic) of Western North America. In Harris et al., (eds.), The Triassic-Jurassic Terrestrial Transition. New Mexico Museum of Natural History and Science, Bulletin, 37: 164-169.

Hunt, A. P. and Lucas, S. G. 2007. Tetrapod ichnofacies: A new Paradigm. Ichnos, 14: 59-68.

Kümmel, S. B. and Frey, E. 2012. Digital arcade in the autopodia of Synapsida: Standard position of the digits and dorsoventral excursion angle of digital joints in the rays II-V. Palaeobiodiversity and Palaeoenvironments, 92: $171-196$.

Kümmel, S. B. and Frey, E. 2014. Range of movement in ray I of manus and pes and the prehensility of the autopodia in the Early Permian to Late Cretaceous Non-Anomodont Synapsida. PLoS ONE, 9(12): e113911. doi:10.1371/journal. pone.0113911.

Leonardi, G. 1977a. On a new occurrence of tetrapod trackways in the Botucatu Formation in the State of São Paulo, Brazil. Dusenia, 10: 181-183.

Leonardi, G. 1977b. Two new ichnofaunas (vertebrate and invertebrate) in the eolian Cretaceous sandstones of the Caiua Formation in northwest Paraná. Atas do I Simpósio de Geologia Regional, Setembro 1977, São Paulo, SP, 112-128.

Leonardi, G. 1980. On the Discovery of an Abundant IchnoFauna (Vertebrates and Invertebrates) in the Botucatu Formation s.s. in Araraquara, São Paulo, Brazil. Anais da Academia Brasileira de Ciências, 52: 559-567.

Leonardi, G. 1981. Novo Ichnogênero de Tetrápode Mesozóico da Formação Botucatu, Araraquara, SP. Anais da Academia Brasileira de Ciências, 53: 793-805.

Leonardi, G. 1987. Glossary and Manual of Tetrapod Footprint Paleoichnology. Conselho Nacional de Desenvolvimento Cientifico e Tecnologico, Brasil, 75 pp.

Leonardi, G. 1989. Inventory and Statistics of the South American Dinosaurian Ichnofauna and its Paleobiological Interpretation. In Gillette, D.D. and Lockley, M.G. (eds.), Dinosaur Tracks and Traces. Cambridge, Cambridge University Press, pp. 165-178.

Leonardi, G. 1992. Sulle prime piste fossili di tetrapodi del Paraguay. Paleocronache, 1992(1): 66-67.

Leonardi, G. 1994. Annotated Atlas of South America Tetrapod Footprints (Devonian to Holocene) with an appendix on México and Central America. Brasília, CPRM, 248 pp.

Leonardi, G. and Carvalho, I. S. 1999. Jazigo Icnofossilífero do Ouro-Araraquara (SP). In Schobbenhaus, C., Campos, D. A., Queiroz, E. T., Winge, M., and Berbert-Born, M. (eds.), Sítios Geológicos e Paleontológicos do Brasil. Brasília, DNPM, pp. 39-48,.

Leonardi, G. and Godoy, L. C. 1980. Novas pistas de tetrápodes da Formação Botucatu no Estado de São Paulo. Anais do
XXXI Congresso Brasileiro de Geologia, 1980. Balneário de Camboriú, Santa Catarina, SBG, 5: 3080-3089.

Leonardi, G. and Oliveira, F. H. L. 1990. A revision of the Triassic and Jurassic tetrapod footprints of Argentina and a new approach on the age and meaning of the Botucatu Formation footprints (Brazil). Revista Brasileira de Geociencias, 20: $216-229$.

Leonardi, G. and Sarjeant, W. A. S. 1986. Footprints representing a new Mesozoic vertebrate fauna from Brazil. Modern Geology, 10: 73-84.

Leonardi, G., Carvalho, I. S., and Fernandes, M. A. 2007. The desert ichnofauna from the Botucatu Formation (Upper Jurassic-Lower Cretaceous), Brasil. In Carvhalho, I.S. et al. (eds.), Paleontologia: Cenários da Vida, Editora Interciênca, Rio de Janeiro, 1: 379-391.

Lockley, M. G. 2011. The ichnotaxonomic status of Brasilichnium with special reference to occurrences in the Navajo Sandstone (Lower Jurassic) in the Western USA. In Sullivan et al., (eds.), Fossil Record 3. New Mexico Museum of Natural History and Science, Bulletin, 53: 306-315.

Lockley, M. G. and Hunt, A. P. 1995. Dinosaur Tracks and Other Fossil Footprints of the Western United States. New York, Columbia University Press, 338 pp.

Lockley, M. G., Hunt, A. P. and Meyer, C. 1994. Vertebrate tracks and the ichnofacies concept: implications for Paleoecology and Palichnostratigraphy. In Donovan, S. (ed.), The Paleobiology of Trace Fossils. New York, Wiley and Sons, pp. 241-268.

Lockley, M. G., Lucas, S. G., Gaston, R., and Hunt, A. P. 2004. Ichnofaunas from the Triassic-Jurassic boundary sequences of the Gateway area, Western Colorado: implications for faunal composition and correlations with other areas. Ichnos, 11: 89-102.

Lockley, M. G., Tedrow, A. R., Chamberlain, K. C., Minter, N. J., and Lim, J.-D. 2011. Footprints and invertebrate traces from a new site in the Nugget Sandstone (Lower Jurassic) of Idaho. Implications for life in the Northern reaches of the Great Navajo-Nugget Erg System in the Western USA. In Sullivan et al., (eds.), Fossil Record 3. New Mexico Museum of Natural History and Science, Bulletin, 53: 344356.

Loope, D. B. 2006. Dry-season tracks in dinosaur-triggered grainflows. Palaios, 21: 132-142.

Lucas, S. G., Spielmann, J. A., Klein, H., and Lerner, A. J. 2010. Ichnology of the Upper Triassic (Apachean) Redonda Formation, East-Central New Mexico. New Mexico Museum Natural History and Science, Bulletin, 47: 1-75.

MacEachern, J. A., Bann, K. L., Gingras, M. K., Zonneveld, J.P., Dashtgard, S. E., and Pemberton, S. G. 2012. The ichnofacies paradigm. In Knaust, D. and Bromley, R. (eds.), Trace Fossils as Indicators of Sedimentary Environments. Developments in Sedimentology Series, 64: 103-138.

McKeever, P. J. and Haubold, H. 1996. Reclassification of vertebrate trackways from the Permian of Scotland and related FORMS from Arizona and Germany. Journal of Paleontology, 70: 1011-1022.

Milan, J., Loope, D. B., and Bromley, R. G. 2008. Crouching theropod and Navahopus sauropodomorph tracks from the Early Jurassic Navajo Sandstone of USA. Acta Paleontologica Polonica, 53: 197-205.

Olsen, P. and Galton, P. 1984. A review of the reptile and amphibian assemblages from the Stormberg of Southern 
Africa, with special emphasis on the footprints and the age of the Stormberg. Palaeontologica Africana, 25: 87-110.

Perea, D., Soto, M., Veroslavsky, G., Martínez, S., and Ubilla, M. 2009. A Late Jurassic fossil assemblage in Gondwana. Biostratigraphy and correlations of the Tacuarembó Formation, Parana Basin, Uruguay. Journal of South American Earth Sciences, 28: 168-179.

Pye, K. and Tsoar, H. 2009. Aeolian Sand and Sand Dunes. Berlin Heidelberg, Springer-Verlag, 457 pp.

Rainforth, E. C. 1997. Vertebrate ichnological diversity and census studies, Lower Jurassic Navajo Sandstone [M.S. research report]: Boulder, University of Colorado, $49 \mathrm{pp}$.

Rainforth, E. C. 2003. Revision and re-evaluation of the Early Jurassic dinosaurian ichnogenus Otozoum. Palaeontology, 46: 803-838.

Renne, P. R., Ernesto, M., Pacca, I. G., Coe, R. S., Glen, J., Prevot, M., and Perrin, M. 1992. The age of Parana flood volcanism, rifting of Gondwanaland, and the JurassicCretaceous boundary. Science, 258: 975-979.

Reynolds, R. E. 2006. Way out West: Jurassic tracks on the continental margin. In Harris et al. (eds.), The TriassicJurassic Terrestrial Transition. New Mexico Museum of Natural History and Science, Bulletin, 37: 232-237.

Reynolds, R. E. and Weasma, T. 2002. California dinosaur tracks: Inventory and management, In Reynolds, R.E. (ed.), Between the basins: Exploring the Western Mojave and Southern Basin and Range Province, 2002 Desert Symposium Proceedings Volume. Fullerton, California, State University at Fullerton, Desert Studies Consortium, pp. 15-19.

Salamuni, R. and Bigarella, J. J. 1967. Botucatu Formation. In Bigarella, J.J., Becker, R.D., and Pinto, I.D. (eds.), Problems in Brazilian Gondwana Geology. 1st International Symposium on the Gondwana Stratigraphy and Paleontology, Mar de la Plata, Argentina, pp. 197-206.

Sanford, R. M. and Lange, F. W. 1960. Basin study approach for oil evaluation of Paraná miogeosyncline of South Brazil.
Bulletin American Association of Petroleum Geologists, 44: 1316-1370.

Santi, G. and Nicosia, U. 2008. The ichnofacies concept in vertebrate ichnology. In Avanzini, M. and Petti, F. M. (eds.), Italian Ichnology. Studi Trentini di Scienze Naturali, Acta Geolocia, 83: 223-229.

Scherer, C. M. S. 2000. Eolian dunes of the Botucatu Formation (Cretaceous) in Southernmost Brazil: morphology and origin. Sedimentary Geology, 137: 63-64.

Scherer, C. M. S. 2002. Preservation of aeolian genetic units by lava flows in the Lower Cretaceous of the Paraná Basin, Southern Brazil. Sedimentology, 49: 97-116.

Seilacher, A. 2007. Trace Fossil Analysis. Berlin, Springer, 226 pp.

Soares, P. C. 1975. Divisão Estratigrafica do Mesozóico no Estado de São Paulo. Revista Brasileira de Geociências, 5: 251-267.

Soares, A. P., Soares, P. C., and Holz, M. 2008. Correlações estratigráficas conflitantes no limite PermoTriássico no Sul da Bacia do Paraná: O contato entre duas seqüências e implicações na configuração espacial do Aqüífero Guarani. Revista Pesquisas em Geociências, 35: 115-133.

Stollhofen, H. 1999. Karoo Syndrift-Sedimentation und ihretektonische Kontrolle am entstehenden Kontinentalrand Namibias. Zeitschrift Deutsche Geologische Gesellschaft, 149: 519-623.

Tamrat, E. and Ernesto, M. 2006. Paleomagnetic constraints on the age of the Botucatu Formation in Rio Grande do Sul, Southern Brazil. Anais da Academia Brasileira de Ciencias, 78: 591-605.

Thulborn, R. A. 1990. Dinosaur Tracks. London, Chapman and Hall, 410 pp.

Turner, S., Regelous, M., Hawkesworth, C., and Montovani, M. 1994. Magmatism and continental break-up in the South Atlantic: High precision ${ }^{40} \mathrm{Ar}-{ }^{39} \mathrm{Ar}$ geocronology. Earth and Planetary Science Letters, 121: 333-348. 